Images in...

\title{
Heart failure due to prosthetic mitral leaflet thrombosis
}

\author{
Umar Hamid Imran, Alan Soo, Carol Wilson, Alastair Graham \\ Department of Cardiothoracic Surgery, Royal Victoria Hospital, Belfast, UK \\ Correspondence to Umar Hamid Imran, umar79@hotmail.com
}

\section{DESCRIPTION}

A 54-year-old patient presented with a 2-week history of progressive dyspnoea. The patient previously underwent mitral valve replacement with a mechanical prosthesis (CarboMedics, Austin, Texas, USA) for rheumatic mitral valve stenosis and coronary artery bypass grafting. Examination revealed absence of prosthetic valve click. The patient's INR was 1.3 on admission. Subsequent investigation including echocardiography and screening fluoroscopy confirmed obstructed leaflet of the prosthetic valve (video 1). The patient was then brought to the operating theatre. Intraoperatively, a large thrombus was found on the atrial surface of the prosthetic valve leaflet obstructing leaflet motion. The obstructed prosthetic valve was then removed and replaced (figure 1). Postoperative recovery was uneventful.

Video 1 Fluoroscopy revealing single leaflet motion in a bileaflet valve indicating valve dysfunction. 10.1136/bcr.03.2011.3969v1

Progress in the design and structure of mechanical prostheses over the years has led to a considerable improvement in their haemodynamic features and durability; however, acute thrombosis of mechanical prosthetic heart valves is one of the major complications of valve replacement. ${ }^{1}$ The risk of thrombosis is dependent on valve design, materials and host-related interface. Clinical finding and loss of valve clicks raise suspicion of mechanical valve thrombosis, which is confirmed by echocardiography. Transoesophageal echocardiography allows accurate visualisation of echos emanating from the atrial surface of the prosthesis corresponding to thrombi. Mortality from re-operation for mitral valve thrombosis is reported to be $29.4 \% .^{2}$

Competing interests None

Patient consent Obtained.

\section{REFERENCES}

1. Roscitano A, Capuano F, Tonelli E, et al. Acute dysfunction from thrombosis of a mechanical mitral valve prosthesis. Braz J Cardiovasc Surg 2005;20:88-90

2. Jones JM, $\mathrm{O}^{\prime}$ kane $\mathrm{H}$, Gladstone DJ, et al. Repeat heart valve surgery: risk factors for operative mortality. J Thorac Cardiovasc Surg 2001;122:913-18.

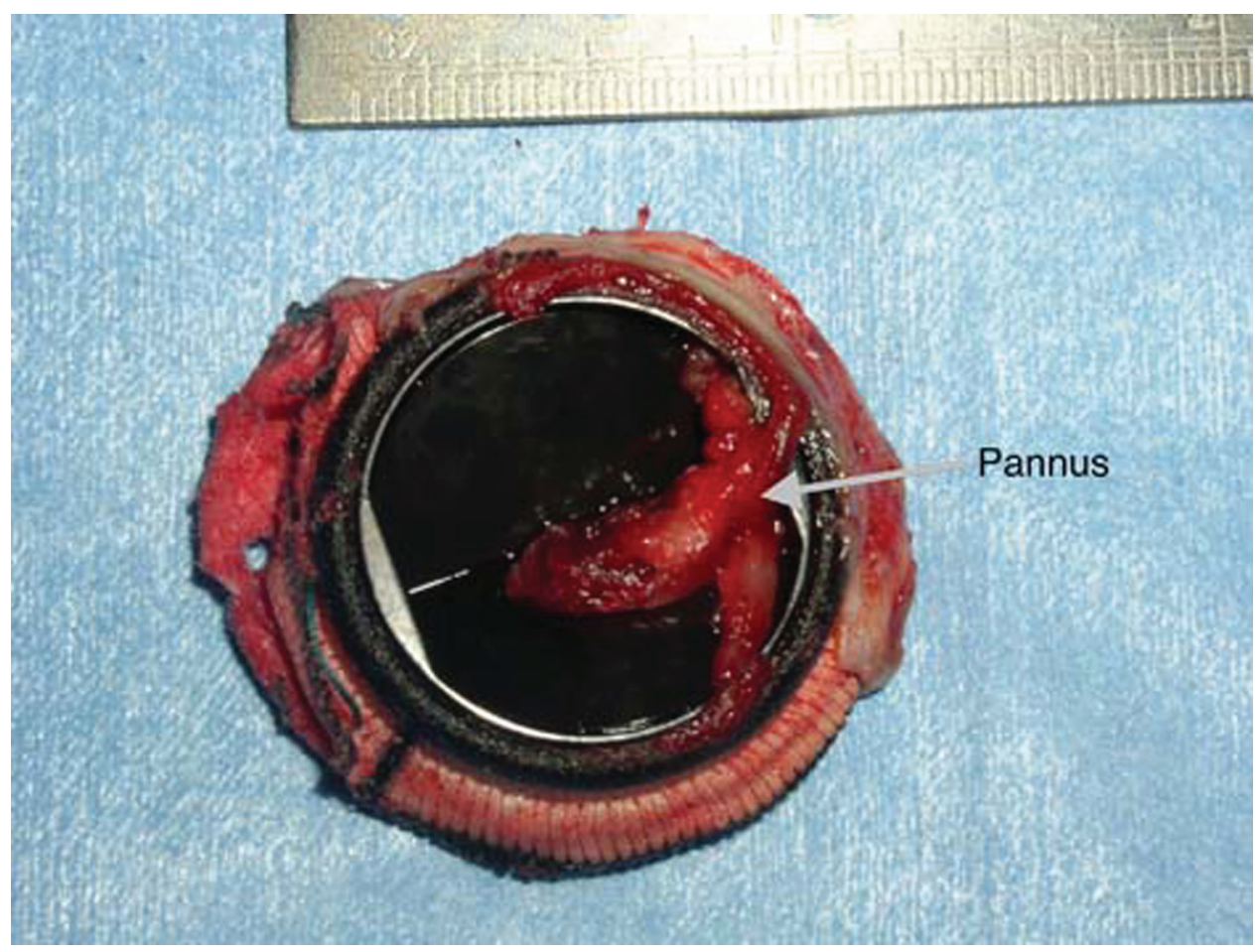

Figure 1 Mechanical mitral valve with pannus obstructing the leaflet. 


\section{BMJ Case Reports}

This pdf has been created automatically from the final edited text and images.

Copyright 2011 BMJ Publishing Group. All rights reserved. For permission to reuse any of this content visit http://group.bmj.com/group/rights-licensing/permissions.

BMJ Case Report Fellows may re-use this article for personal use and teaching without any further permission.

Please cite this article as follows (you will need to access the article online to obtain the date of publication).

Imran UH, Soo A, Wilson C, Graham A. Heart failure due to prosthetic mitral leaflet thrombosis. BMJ Case Reports 2011;10.1136/bcr.03.2011.3969, date of publication

Become a Fellow of BMJ Case Reports today and you can:

- Submit as many cases as you like

- Enjoy fast sympathetic peer review and rapid publication of accepted articles

- Access all the published articles

- Re-use any of the published material for personal use and teaching without further permission

For information on Institutional Fellowships contact consortiasales@bmjgroup.com

Visit casereports.bmj.com for more articles like this and to become a Fellow 